\title{
Przezwyciężenie kryzysu uchodźczego w UE z punktu widzenia niemieckiej polityki rozwojowej
}

\section{Wprowadzenie}

Nasilające się kryzysy, począwszy od Syrii i Iraku, poprzez Ukrainę, Jemen, po Południowy Sudan zintensyfikowały zainicjowane w 2014 r. dyskusje wokół rewizji roli i odpowiedzialności Niemiec w kształtowaniu międzynarodowego bezpieczeństwa i pokoju. Implikacje wspomnianych konfliktów poza wymiarem militarnym, zaostrzają humanitarne i rozwojowe wyzwania, przed którymi stoi społeczność międzynarodowa. Co więcej, potęgują one globalny kryzys uchodźczy. W 2015 r. 65,3 mln osób znalazło się na uchodźstwie, osiagając tym samym najwyższy poziom od drugiej wojny światowej (UNHCR, 2016). Współpraca rozwojowa w coraz większym stopniu pretenduje do roli instrumentu pozwalającego na wyeliminowanie ponadgranicznych źródeł zagrożeń dla międzynarodowego bezpieczeństwa. Masowy napływ imigrantów do Europy jest niewątpliwie jednym z najważniejszych tematów wyznaczających obecnie europejską i zarazem niemiecką debatę publiczną. Co więcej, zmniejsza się gotowość państw do stawienia czoła kryzysowi uchodźczemu, a ograniczenie imigracji zaczyna być postrzegane jako jeden z warunków zapewnienia bezpieczeństwa kraju. Przedmiotem analizy jest koncepcja i zaangażowanie pomocy rozwojowej Niemiec w przezwyciężanie kryzysu uchodźczego. W pierwszej części artykułu zarysowano ogólne uwarunkowania pomocy dla uchodźców przez pryzmat jej znaczenia dla sfery bezpieczeństwa, zaś w części drugiej zaprezentowano politykę rozwojową Niemiec w tym zakresie.

\section{Zwalczanie przyczyn uchodźstwa - wpływ kwestii bezpieczeństwa na rolę współpracy na rzecz rozwoju}

Niewątpliwie międzynarodowa migracja, jako zjawisko towarzyszące procesom globalizacyjnym należy do największych wyzwań XXI w. (Stockmann, Menzel, Nuscheler, 2016, s. 358-374). Współczesna debata wokół wzmożonych ruchów migracyjnych, a także związane z nią badania pozostają pod silnym wpływem zmian dokonujących się w przestrzeni politycznej. Po atakach terrorystycznych z września $2001 \mathrm{r}$. kluczowymi hasłami rozpoczynającego się milenium stały się terroryzm i bezpieczeństwo. W konsekwencji również pomoc humanitarna i współpraca na rzecz rozwoju zostały włączone w szeroko pojętą koncepcję bezpieczeństwa. Postrzeganie stanu bezpieczeństwa przez pryzmat tragicznych wydarzeń wywarło wpływ na międzyna- 
rodową percepcję osób przesiedlonych, ubiegających się o azyl i uchodźców. W coraz większym stopniu identyfikuje się tę grupę jako stwarzającą przesłanki dla zagrożeń bądź stanowiącą zagrożenie, obciążenie lub problem, który implikuje dalsze kłopoty i trudności (Harmer, Macrae, 2004, s. 4-5). Zadaniem współpracy rozwojowej jest już nie tylko powiązanie pomocy i rozwoju, ale również pomocy i bezpieczeństwa. $Z$ jednej strony, wysokorozwinięte społeczeństwa Północy zaostrzają swoje prawo azylowe i politykę w tym obszarze, tak by stworzyć mechanizmy ochronne na przyszłość. $\mathrm{Z}$ drugiej strony, rozwijające się kraje Południa nie są zdolne sprostać powiększającej się liczbie uchodźców, jednocześnie same borykając się z brakiem bezpieczeństwa.

Od zakończenia zimnej wojny rosnącej wielkości wsparcia towarzyszył wzrost znaczenia interesów bezpieczeństwa głównych donatorów. Oficjalna pomoc rozwojowa stała się podstawową płaszczyzną dynamicznie rozwijającej się architektury globalnego zarządzania (por. Bilzen van, 2015). Jest ona zarazem elementem nowoczesnej, szeroko zakrojonej polityki zagranicznej, która nie ogranicza się wyłącznie do forsowania narodowych interesów, lecz ma na uwadze również kształtowanie globalnego środowiska. W miejsce zimnej wojny pojawiły się w tym samym czasie nowe źródła odczuwalnych globalnych zagrożeń, jak ,nowe wojny”, rosnąca liczba państw niestabilnych czy międzynarodowy terroryzm. Niedorozwój społeczno-ekonomiczny oraz słabe rządy uznane zostały za główny czynnik implikujący wewnętrzne konflikty i niestabilność państwa w wielu krajach (Brown, Grävingholt, 2016, s. 1-15).

W zarysowanym kontekście dyskurs rozwojowy pozostaje pod wpływem teorii sekurytyzacji (securitization), reprezentowanej przez tzw. szkołę kopenhaską. Podkreśla ona m.in. intersubiektywny proces poszerzania rozumienia bezpieczeństwa przez poszczególnych aktorów i włączania nowych zagadnień, tradycyjnie z nim niezwiązanych (Fijałkowski, 2012; Duffield, 2007). Argumenty, uzasadniające pomoc dla rozwijających się państw niestabilnych oscylują między negatywnym efektem spill over dla ładu międzynarodowego a niedopuszczeniem do powstania kolejnej „twierdzy terrorystów" (Brown, Grävingholt, 2016, s. 1). Nowe wyzwania znajdują odzwierciedlenie w strategiach pomocowych państw i organizacji międzynarodowych, przykładem jest zwiększenie pomocy dla dotkniętych konfliktem państw (Irak i Afganistan) czy kluczowych sojuszników w walce przeciwko terroryzmowi (Pakistan i Etiopia) (zob. Paterek, 2015). Towarzyszy temu jednocześnie wypracowanie na poziomie rządowym kompleksowych podejść scalających aktywność wielu resortów (Niemcy zob.: Paterek, 2015; Francja, Wielka Brytania, USA, Kanada zob.: Brown, Grävingholt, 2016). Zwraca się uwagę na kontrowersyjność tzw. sekurytyzacji pomocy rozwojowej, bowiem interwencje militarne, często podejmowane w imię dobra obywateli państw docelowych, zyskują dzięki temu uprawomocnienie i uzasadnienie (Duffield, 2007; Brown, Grävingholt, 2016, s. 2-3).

Niemiecką dyskusję nad rolą polityki rozwojowej w przezwyciężaniu nowych wyzwań, w szczególności kryzysu uchodźczego kształtuje przede wszystkim aktywność Niemieckiego Instytutu Polityki Rozwojowej z siedzibą w Bonn (das Deutsche Institut für Entwicklungspolitik - DIE), który rozpoczął swoją działalność w 1965 r., cztery lata po utworzeniu Federalnego Ministerstwa Współpracy Gospodarczej i Rozwoju (das Bundesministerium für wirtschaftliche Zusammenarbeit und Entwicklung BMZ). Należy on do czołowych, o światowym zasięgu think thanków, specjalizujących się 
w zagadnieniach globalnego rozwoju i współpracy międzynarodowej. Zgodnie z przyjętą maksymą jest łącznikiem pomiędzy teorią i praktyką, integruje badania, doradztwo i kształcenie. Badania prowadzone w ramach DIE opierają się na teoretycznych podstawach, wspartych empirycznie i aplikowalnych. DIE wypracowuje politycznie istotne koncepcje, doradza ministerstwom, rządom i organizacjom międzynarodowym oraz zajmuje stanowisko wobec aktualnych politycznych kwestii.

Dirk Messner, dyrektor DIE w opublikowanym we wrześniu 2015 r. w „Zeit Online" artykule zatytułowanym Kryzys uchodźczy: Duże problemy wymagaja dużych rozwiazań argumentuje, że zarówno Europa, jak i Niemcy nie będą ,wyspami szczęśliwców, bowiem ponadgraniczne kryzysy nie znikną dzięki murom, odwracaniu wzroku i bezczynności”. Jego zdaniem lekcją którą należy wyciagnąć z 2015 roku jest konieczność długofalowej międzynarodowej i globalnej współpracy. Przyszły dobrobyt i demokracja wymagają trwałego opanowania „efektu bumerangowego” kompleksowego procesu globalizacji. Dla przezwyciężenia kryzysu uchodźczego Messner proponuje pięciopunktowy plan, którego przeprowadzenie pozwoli na ograniczenie dynamiki eskalacji kryzysu i jednocześnie zapewni ochronę „życia ludzkiego i tym samym naszego wyobrażenia o humanitaryzmie”. Niemniej ,żadna z koniecznych inicjatyw nie jest łatwa, niezbędna jest cierpliwość, duże nakłady i odważne polityczne reformy". Pierwszy sformułowany przez niego postulat wiąże się z wypracowaniem nowego ładu w regionie Bliskiego Wschodu i Afryki Północnej. Europa wraz z USA, Rosją, Iranem, Arabią Saudyjską, Egiptem i Tunezją powinny zainicjować multilateralny proces długofalowej stabilizacji takich państw jak Syria, Irak, Libia, Jemen, który pozwoliłby na „zapobieżenie upadkowi państw, wojnie, islamskiemu terrorowi i tragedii uchodźców". Drugą kwestią jest wypracowanie dla obecnie już przeszło 60 mln uchodźców „sprawiedliwych i godnych” rozwiązań na płaszczyźnie międzynarodowej. Zwłaszcza że ich liczba „drastycznie wzrośnie jeśli zawiedzie globalna polityka klimatyczna”. Należy „masowo” wspierać kraje z dużą liczbą uchodźców przypadającą na jednego mieszkańca, jak Jordania, Liban, Turcja, Pakistan, Uganda czy Czad, sprawiedliwie rozdzielać koszty, tworzyć multilateralnie chronione strefy, obozy dla uchodźców, dające im perspektywy rozwoju. Trzecim dezyderatem adresowanym zarówno do Niemiec, jak i do Europy jest ,godne przyjęcie i integracja uchodźców". Chodzi tu o zintegrowanie polityki uchodźczej z migracyjna, pogodzenie wyzwań natury finansowej, instytucjonalnej, społecznej, edukacyjnej, moralnej czy rynku pracy. Uwzględnić należy m.in. zrównoważenie własnych interesów oraz interesów uchodźców i migrantów, sposób kształtowania migracji cyrkulacyjnej, wsparcie możliwości zatrudnienia uchodźców i ich późniejsze włączenie do ustabilizowanych krajów pochodzenia. Czwarty postulat dotyczy walki z przyczynami uchodźstwa. Należą do nich wojny, brak perspektyw związanych z sytuacją gospodarcza, dyktatury. Zaangażowanie w krajach kryzysowych jest kosztowne, wymaga czasu i kreatywności, ale nie ma dla niego alternatywy. Messner wzywa do nowego ukierunkowania i rozbudowy polityki wobec Afryki, a także wzmocnienia europejskiego zaangażowania na Bałkanach. Co więcej to ,skuteczna polityka klimatyczna jest prewencyjną polityką wobec uchodźców". Ostatnim, piątym punktem planu jest „długofalowa polityka edukacyjna”. Messner podkreśla, że kolejne pokolenia „muszą nauczyć się żyć w otwartym, heterogenicznym społeczeństwie migracyjnym”. Celem 
jest wykształcenie ,światowego obywatela”, obeznanie z islamem, umiejętność radzenia sobie z konfliktami nie do uniknięcia, tolerancja, poszanowanie demokracji i praw człowieka. Globalna współpraca i zarazem perspektywa są warunkiem pokoju i dobrobytu we wzajemnie powiązanym świecie. I tak jak Immanuel Kant pod koniec XVIII w. mówił o tym, że nie wystarczy być obywatelem jednego państwa, lecz trzeba nim być w wymiarze światowym, w XXI w. ten postulat powinien być w przekonaniu Messnera „nie tylko moralnym kompasem, lecz również gwarancją tego, że międzynarodowa społeczność nie zatonie na morzu niesterowalnych konfliktów i kryzysów" (Messner, 2015).

Podobne akcenty można odnaleźć w jego kolejnym artykule ze stycznia 2016 r., zatytułowanym Światowe kryzysy, wizja świata, przełomy. Messner podkreśla znaczenie „symboli i znaków” w polityce. Takim sygnałem ze strony UE i jej państw członkowskich, wyrażającym z jednej strony sprzeciw wobec odrodzeniu się nacjonalizmów i zamknięciu granic państw, a z drugiej strony poparciem dla globalnej współpracy będzie podniesienie wielkości oficjalnej pomocy rozwojowej z obecnego poziomu $0,42 \%$ DNB do dawno zapowiedzianego $0,7 \%$. Byłby to „program inwestycyjny dla globalnego rozwoju i europejskiej stabilności w rzędzie wielkości ok. 40 mld euro - a zatem 80 euro na obywatela UE". Tym samym, w przekonaniu Messnera, Europa da polityczny sygnał woli i zrozumienia, że „globalne przezwyciężanie kryzysów, inwestycje w światowy dobrobyt i europejski rozwój są ze sobą bezpośrednio powiązane”. Co więcej, międzynarodowa współpraca jest „polityką pokoju i chroni przed zagrażającym bezpieczeństwu nacjonalizmem”, a Europa jest współodpowiedzialna za ochronę globalnych dóbr wspólnych. Zatem możliwe, że „,pierwszy globalny sygnał do współpracy musi zostać zainicjowany bez wsparcia Węgier i Polski”. Bowiem duże polityczne zmiany wymagają wysiłku i długofalowej perspektywy.

Zdaniem Messnera wspólnym mianownikiem wyzwań ostatnich lat jest występowanie ponadgranicznych, globalnych współzależności, które implikują niemożność osiagnięcia narodowego dobrobytu i bezpieczeństwa przy braku bezpieczeństwa na poziomie międzynarodowym. Współczesne kryzysy wzmacniają cztery trendy. Jako pierwszy wymienia ubóstwo, nierówność i wykluczenie społeczne, które „są pożywką dla apatii, rezygnacji, przemocy, rozkładu/upadku społecznego, uchodźstwa". Tak jest w przypadku m.in. „Iraku, Jemenu, Erytrei, Birmy/Myanmar, Pakistanu i Indii, w USA, belgijskim Molenbeek czy paryskich przedmieściach”. Zależności pomiędzy tymi zjawiskami są często ignorowane, dopóki „apatia nie przerodzi się w agresję".

Drugą kwestią jest konieczność osiagania dobrobytu w granicach ekosystemu i „dokonanie pełnego rozdziału rozwoju od konsumpcji zasobów i emisji” w nadchodzących generacjach. W przeciwnym razie ,grożą nam konflikty na tle podziału dóbr, nowe fale biedy i ruch migracyjny, znacznie przewyższający obecny". Trzecim zjawiskiem jest transnarodowy terroryzm islamski. Podobnie jak faszyzm i stalinizm to kolejny ruch totalitarny, który „mobilizuje ludzi poprzez oferowanie identyfikacji i kreowanie radykalnych światów opozycyjnych". Jako czwarty trend Messner zwraca uwagę na kształtowanie się ,centrowej »międzynarodówki« autorytarnych nacjonalistów, ksenofobów, stawiających płoty i upraszczaczy”, w reakcji na „rzeczywiste i domniemane ciemne strony globalizacji”. W jego przekonaniu to właśnie „Le Pen, 
Orban, nowy polski rząd, Pegida ${ }^{1}$, a także bratnie dusze jak Putin i Trump zagrażają wolności, tolerancji i współpracy międzynarodowej” (Messner, 2016).

W towarzyszących zaostrzającej się sytuacji wokół uchodźców stanowiskach i analizach publikowanych przez ekspertów DIE powtarzała się konstatacja o prewencyjnej roli polityki rozwojowej w łagodzeniu przyczyn uchodźstwa (Schraven, Keijzer, 2014; Hackenesch, Leininger, 2015; Schraven, Trautner, Leininger, Loewe, Grävingholt, 2015; Schraven, Keijzer, Knoll, 2014). Jej celem powinno być zapobieganie kryzysom i wspieranie pokoju. Przy czym należy różnicować polityczne i gospodarcze instrumenty służące niwelowaniu źródeł uchodźstwa i dostosowywać je w zależności od swoistości danego społeczeństwa. Jednocześnie szczególne znaczenie przypisuje się wsparciu reform strukturalnych, służących kształtowaniu dobrych rządów i sprawnie funkcjonującego aparatu państwowego. Niemniej współpraca rozwojowa winna być elementem uzupełniającym politykę zagraniczną i wewnętrzną, kształtowanym jako ,polityka bezpieczeństwa dla ludzi”. W ten sposób możliwy będzie „mocniejszy wkład rozwojowy w politykę uchodźczą" (Hackenesch, Leininger, 2015).

Na dylemat związany ze zwiększaniem wsparcia finansowego dla zwalczania przyczyn uchodźstwa w krajach pochodzenia zwraca uwagę w artykule zatytułowanym Żadnych pieniędzy pomocowych dla skorumpowanych kleptokratów Theo Sommer, były redaktor naczelny i wydawca „Die Zeit”. W jego przekonaniu dodatkowe pieniądze trafiając w ręce skorumpowanych polityków, przyniosą wręcz przeciwny skutek, a mianowicie przyczynią się do zwiększenia liczby uchodźców. Ponadto powołując się na opinie wielu ekonomistów uważa że wsparcie finansowe ,uzależnia, zabija własną inicjatywę zamiast dawać impulsy do samodzielnego działania i jest pożywką dla korupcji” (Sommer, 2015).

\section{Strategia i zaangażowanie niemieckiej pomocy rozwojowej w przeciwdziałanie kryzysowi uchodźczemu}

Uwarunkowania kształtujące ramy niemieckiej polityki rozwojowej na początku XXI w. pod rządami koalicji SPD i Sojusz'90/Zieloni pociagnęły za sobą wzmocnienie znaczenia współpracy rozwojowej. Weszła ona w skład kompleksowej globalnej polityki na rzecz pokoju, ukierunkowanej na wspieranie zmian strukturalnych, mających na celu redukcję ubóstwa, zrównoważony rozwój gospodarczy, promocję demokracji i praw człowieka, zwalczanie przyczyn konfliktów, zrównoważone wykorzystanie zasobów naturalnych w krajach partnerskich (BMZ, 2001, s. XI). Odtąd polityka rozwojowa była istotnym komponentem niemieckiej polityki bezpieczeństwa w zakresie prewencji kryzysowej (zob. Hacke, 2003, s. 489), której zadaniem było stworzenie godnych warunków życia w krajach rozwijających się i tym samym również zabezpieczenie własnej przyszłości.

Po raz pierwszy koncepcję Polityki uchodźczej w ramach współpracy rozwojowej wypracował w 1994 r. chadecki minister Carl-Dieter Spranger (1991-1998). Zakładała ona: przeciwdziałanie przyczynom uchodźstwa w krajach pochodzenia, złagodzenie

${ }^{1}$ Patriotische Europäer gegen die Islamisierung des Abendlandes (Patriotyczni Europejczycy przeciw Islamizacji Zachodu) niemieckie antyislamskie i antyimigracyjne stowarzyszenie powstałe w $2014 \mathrm{r}$. 
negatywnych następstw uchodźstwa w docelowych krajach rozwijających się, a także wspieranie powrotów i ponownego włączenia uchodźców do krajów rodzinnych.

Zredukowanie przyczyn uchodźstwa obejmowało przede wszystkim działania na rzecz poprawy uwarunkowań politycznych, m.in. respektowania praw człowieka, udziału społeczeństwa w procesach decyzyjnych, stworzenia demokratycznych, praworządnych i wolnorynkowych struktur. Zaliczono tu również zapobieganie katastrofom, głównie w zakresie ochrony środowiska i zasobów naturalnych w krajach rozwijających się. Złagodzenie następstw uchodźstwa w krajach przyjmujących podporządkowano przygotowaniu na powrót do krajów pochodzenia. Dlatego też do najważniejszych instrumentów zaliczono: wzmocnienie „woli samopomocy i samoorganizacji wśród uchodźców”, przeciwdziałanie „obozowemu” hospitalizmowi, wzmocnienie gospodarczej niezależności dzięki stworzeniu możliwości zarobkowych, kształcenie odpowiednio do potrzeb kraju pochodzenia, „rehabilitację” strat powstałych w wyniku uchodźców w krajach przyjmujących. Powrót oraz włączenie uchodźców i migrantów do swoich krajów pochodzenia potraktowano jako ,pierwszoplanowy cel” pod warunkiem zaistnienia takiej możliwości. W zależności od stopnia kondycji państwa brano pod uwagę: uruchomienie pomocy finansowej „na start”, a także instrumentów kredytowych w przypadku w miarę stabilnych krajów, natomiast działania rehabilitacyjne zintegrowane z włączeniem społecznym powracających uchodźców, wewnętrznie przesiedlonych i byłych żołnierzy w razie konieczności odbudowy zniszczonego wojną kraju (BMZ, 1995, s. 67-68).

Rząd CDU/CSU/SPD w umowie koalicyjnej z grudnia 2013 r. Ksztattować przyszłość Niemiec wśród celów polityki rozwojowej wymienia walkę z głodem i ubóstwem oraz wzmocnienie demokracji i rządów prawa „w oparciu o nasze wartości i interesy" (Bundesregierung, 2013, s. 180). Niemiecka pomoc wspiera pokój, wolność, bezpieczeństwo, poszanowanie oraz urzeczywistnianie politycznych i socjalnych praw człowieka, ochronę środowiska, społeczną i ekologiczną gospodarkę rynkową, dobre rządzenie oraz zaangażowanie społeczeństwa obywatelskiego. Jednocześnie polityka rozwojowa ma służyć „pomocą dla samopomocy”. Podobnie jak poprzednie ekipy rządowe koalicja CDU/CSU/SPD postrzega współpracę rozwojową w kategoriach globalnej polityki strukturalnej, a mając na uwadze jej prewencyjny charakter uznaje ją za „perspektywiczną politykę pokojową” (Bundesregierung, 2013, s. 180-181). Cele polityki rozwojowej zawarte $\mathrm{w}$ umowie koalicyjnej przywołuje wypracowana w 2014 r. przez Federalnego Ministerstwa Współpracy Gospodarczej i Rozwoju (BMZ) pod egidą chadeckiego polityka Gerda Müllera (CSU) Karta przyszłości. Jeden świat - nasza odpowiedzialność (BMZ, 2014). Karta przyszłości jest ogólną, opartą na wartościach wizją współpracy rozwojowej, ukierunkowanej na osiąnięcie na poziomie narodowym i globalnym celu zrównoważonego rozwoju. W duchu etycznej odpowiedzialności podkreślone zostało znaczenie działań skierowanych na zewnątrz szczególnie w czasach nasilających się kryzysów i zbrojnych konfliktów, natomiast powiązany gospodarczo świat wymaga międzynarodowej współpracy dla przezwyciężenia wspólnych problemów. Karta wyznacza hierarchię niemieckich priorytetów przy realizacji Agendy $2030^{2}$ z uwzględnieniem trzech rozpoczętych w 2014 r. specjalnych

${ }^{2}$ Przyjęte we wrześniu 2015 r. na forum ONZ nowe ramy polityki rozwojowej na lata 20152030 tzw. Cele Zrównoważonego Rozwoju (Sustainable Development Goals - SDGs), stanowią rozwinięcie i kontynuację Milenijnych Celów Rozwoju. 
inicjatyw: walki z głodem, reintegracji uchodźców i rozwiązania kryzysu na Bliskim Wschodzie.

W swojej dotychczasowej aktywności Gerd Müller kładł nacisk na bezpieczeństwo żywnościowe i rozwój obszarów wiejskich, stabilizację regionów kryzysowych na Bliskim Wschodzie oraz przeciwdziałanie przyczynom uchodźstwa. Wychodząc naprzeciw kompleksowym wyzwaniom kryzysu uchodźczego dążył do powiązania niemieckiego zaangażowania humanitarnego wraz ze wsparciem strukturalnego rozwoju państw przyjmujących i reintegracji uchodźców (BMZ, 2014a). Wizja roli współpracy rozwojowej w działaniach wobec uchodźców ministra Müllera nawiązuje do wspomnianej wyżej koncepcji Carla-Dietera Sprangera. Jej celem jest wkład w przezwyciężenie ,strukturalnych i doraźnych przyczyn uchodźstwa, wsparcie regionów przyjmujących, reintegracja i działania na rzecz społecznej i politycznej stabilizacji” (BMZ, 2014a).

Niemcy należą do światowej czołówki donatorów pomocy dla krajów rozwijających się. Według wstępnych danych OECD za rok 2015 pod względem wielkości przekazywanej oficjalnej pomocy rozwojowej (Official Development Assistance - ODA) zajmowały trzecią po USA i Wielkiej Brytanii pozycję wśród 28 członków Komitetu Pomocy Rozwojowej DAC (por. wykres 1). Niemiecka ODA w 2015 r. wyniosła 17,78 mld USD, co stanowiło $0,52 \%$ DNB (por. wykres 2), osiagając tym samym najwyższy dotychczasowy poziom (OECD, 2016b, s. 199). W stosunku do roku 2014 jej wartość zwiększyła się realnie o $25,9 \%$, głównie z uwagi na wzrost wewnętrznych kosztów związanych z uchodźcami (OECD, 2016b, s. 199).

Wykres 1. ODA krajów DAC w 2015 r. (w mld USD)

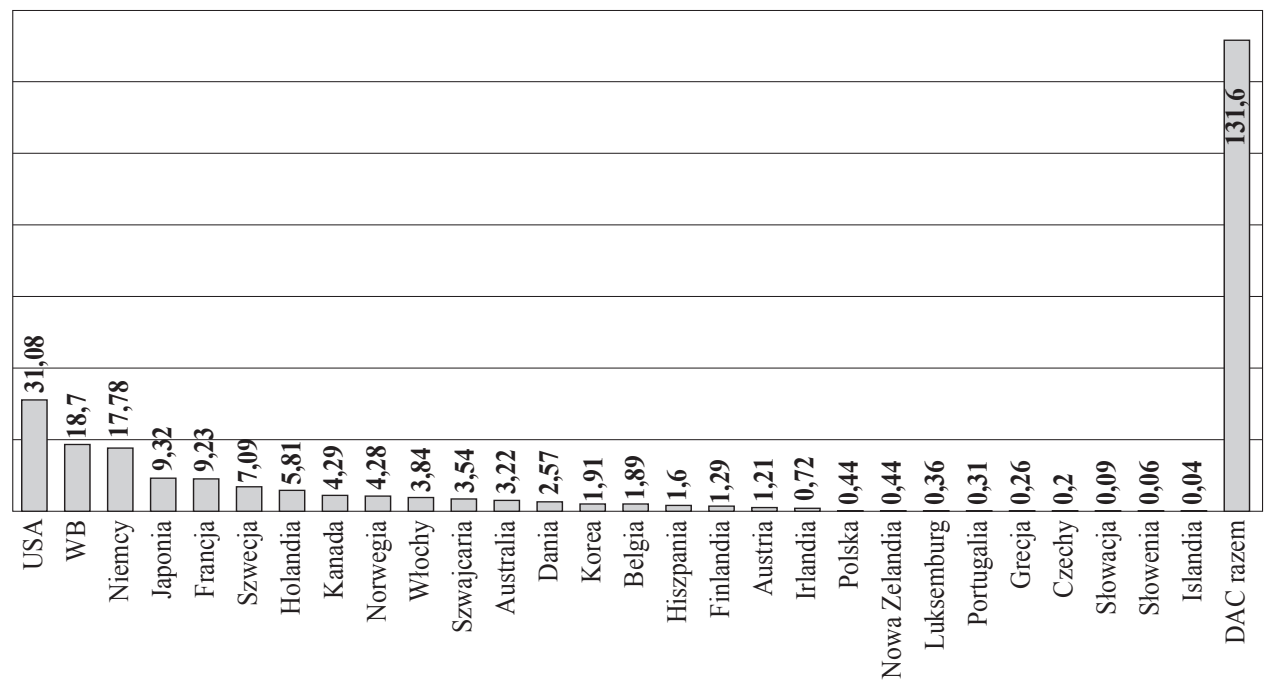

Źródło: OECD, stan na: 13 kwietnia 2016, http://www.oecd.org/dac/stats/ODA-2015-detailed-summary.pdf, s. 7.

Umowa koalicyjna CDU/CSU i SPD z 2013 r. podtrzymała międzynarodowe zobowiązanie Niemiec do osiągnięcia ODA na poziomie 0,7\% DNB. Na okres 2014-2019 rząd federalny zapowiedział zwiększenie budżetu ODA o 10,3 mld euro (DAC-Prüfbericht über die Entwicklungszusammenarbeit: Deutschland, 2015, s. 17). W odpowie- 
dzi na nasilającą się falę uchodźców 6 września 2015 r. komisja koalicyjna CDU/ CSU i SPD zapowiedziała m.in. koncentrację środków BMZ na zwalczanie przyczyn uchodźstwa w najważniejszych krajach pochodzenia i dodatkowe 3 mld euro dla wsparcia landów i gmin związanych z masowym napływem uchodźców i szukających azylu do Niemiec (BMZ, 2016).

\section{Wykres 2. Udzial ODA w DNB (\%) w 2015 roku w państwach czlonkowskich DAC OECD}

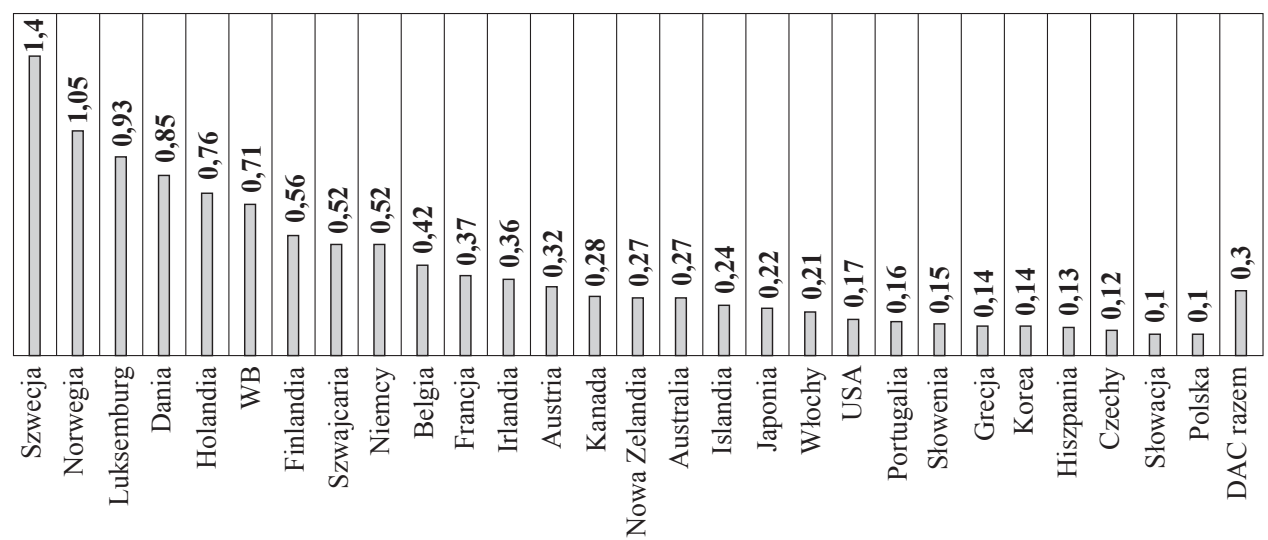

Źródło: OECD, stan na: 13 kwietnia 2016, http://www.oecd.org/dac/stats/ODA-2015-detailed-summary.pdf, s. 7 .

Mimo że wsparcie uchodźców nie należy do mandatu polityki rozwojowej w Niemczech, jego koszty częściowo mogą być włączone w niemiecką oficjalną pomoc rozwojową. Według definicji ODA OECD kraje przyjmujące mogą wliczyć nakłady pieniężne na uchodźców bądź azylantów w ODA w pierwszym roku ich pobytu. Obejmuje to koszty transportu, noclegu, opieki, kursy językowe i dobrowolny powrót do krajów pochodzenia (OECD, 2012). W związku ze znacznym wzrostem liczby uchodźców w ostatnich latach (zob. tabela 1) osiągną one rekordowy poziom w 2016 r. Według danych Federalnego Urzędu ds. Migracji i Uchodźców (Bundesamt für Migration und Flüchtlinge - BAMF) pomiędzy styczniem a lipcem 2016 r. złożono już 479620 pierwszych i ponownych wniosków o azyl, a zatem więcej niż w całym 2015 r. (476 649) (bpb, 2016).

Tabela 1

ODA dla uchodźców w Niemczech w latach 2006-2015

\begin{tabular}{|l|c|c|c|c|c||}
\hline ODA dla uchodźców w Niemczech (w mln USD) & $\mathbf{2 0 0 6}$ & $\mathbf{2 0 0 7}$ & $\mathbf{2 0 0 8}$ & $\mathbf{2 0 0 9}$ & $\mathbf{2 0 1 0}$ \\
& 18,4 & 14,1 & 73,4 & 69,6 & 81,2 \\
\hline Liczba wniosków o azyl & 30100 & 30303 & 28018 & 33033 & 48589 \\
\hline ODA dla uchodźców w Niemczech (w mln USD) & $\mathbf{2 0 1 1}$ & $\mathbf{2 0 1 2}$ & $\mathbf{2 0 1 3}$ & $\mathbf{2 0 1 4}$ & $\mathbf{2 0 1 5}$ \\
& 86,1 & 75,9 & 138,8 & 171,4 & 2993 \\
\hline Liczba wniosków o azyl & 53347 & 77651 & 127023 & 202834 & 476649 \\
\hline
\end{tabular}

Źródło: Welthungerhilfe, 2016, s. 21; OECD, 2016a. 
Na międzynarodowej konferencji w sprawie pomocy dla syryjskich uchodźców w Berlinie w październiku 2014 r. minister Müller określił sytuację w Syrii mianem katastrofy stulecia. Dodatkowo pogłębia ją terror Państwa Islamskiego. Wezwał społeczność międzynarodową do większego zaangażowania we wsparcie krajów sąsiadujących, które nie potrafią sprostać naporowi uciekinierów, jak Jordania, Turcja i Liban. Bowiem „ich zaangażowanie dla uchodźców nie może zagrażać przyszłości ich społeczeństw, czy nawet ich własnej stabilności" (Müller, 2014). W związku z tym konieczne są inwestycje w infrastrukturę, edukację, „,w przyszłość”, bezpośrednio dla uchodźców i dla państw przyjmujących. Zdaniem niemieckiego ministra ,tylko pod warunkiem tego, że obie strony będą miały się lepiej, zapobiegniemy nowym konfliktom" (Müller, 2014).

Zaostrzająca się sytuacja w Syrii pociagnnęła za sobą decyzję rządu federalnego o zaprzestaniu państwowej współpracy rozwojowej z tym krajem w maju $2011 \mathrm{r}$. Z końcem kwietnia 2011 r. Syrię opuścili wszyscy niemieccy eksperci. Od 2012 r. łącznie Niemcy przekazały 1,46 mld euro na walkę z kryzysem, w tym: z budżetu Urzędu ds. Zagranicznych (Auswärtiges Amt - AA) 670 mln euro na pomoc humanitarną i $91 \mathrm{mln}$ euro na zwalczanie kryzysu, a BMZ 699 mln euro na działania strukturalne. Na kolejnej konferencji dawców w Londynie 4 lutego 2016 r., której mottem było „Wsparcie Syrii i regionu” rząd federalny zobowiązał się przekazać 1,2 mld euro w 2016 r., a do 2018 r. łącznie 2,3 mld euro. Tym samym Niemcy są trzecim bilateralnym dawcą pomocy dla Syrii.

Przezwyciężeniu kryzysu uchodźczego niemiecka polityka rozwojowa przypisuje „,najwyższy priorytet”. W 2015 r. BMZ przeznaczyło ponad miliard euro na bezpośrednią pomoc dla uchodźców. Na okres trwającej kadencji 2013-2017 ministerstwo wyasygnuje łącznie ponad 12 mld euro na rzecz przezwyciężania strukturalnych przyczyn uchodźstwa, wsparcie uchodźców i stabilizację regionów przyjmujących. Regionalnie niemieckie zaangażowanie koncentruje się na krajach sąsiadujących z Syrią, Jemenie, Afryce Północnej i Zachodniej, Rogu Afryki, Sudanie Południowym, Bałkanach Zachodnich i Ukrainie, a także Afganistanie i Pakistanie.

W 2014 r. BMZ w reakcji na pojawiające się potrzeby międzynarodowe uruchomiło trzy specjalne inicjatywy: 1) przezwyciężanie przyczyn uchodźstwa - reintegracja uchodźców, 2) stabilizacja i rozwój w Afryce Pótnocnej i na Bliskim Wschodzie, 3) świat bez głodu. Z punktu widzenia kryzysu uchodźczego realizacja wszystkich obejmuje trzy płaszczyzny, które się wzajemnie uzupełniają i przenikają: przezwyciężanie przyczyn uchodźstwa, stabilizacja regionów przyjmujących oraz wsparcie uchodźców, przesiedlonych i powracających.

W 2015 r. na finansowanie inicjatyw przewidziano 200 mln euro, w 2016 r. środki mają osiaggnąc 590 mln euro (Bundeshaushaltsplan, 2015; Bundeshaushaltsplan,

${ }^{3}$ Gospodarzami konferencji były Wielka Brytania, Niemcy, Norwegia, Kuwejt i ONZ. Jej celem było wyjście naprzeciw trudnej finansowej sytuacji organizacji pomocowych ONZ w Syrii i państwach granicznych. Uczestnicy syryjskiej konferencji w Londynie zobowiązali się wyasygnować ponad 9 mld euro na działania służące przezwyciężaniu konsekwencji kryzysu uchodźców w Syrii i wokół niej. Środki mają służyć polepszeniu warunków życia w Syrii i krajach granicznych: wszystkie dzieci-uchodźcy w regionie mają uzyskać dostęp do edukacji, polepszona ma zostać służba zdrowia i możliwości pracy dla uchodźców w krajach sąsiadujących. Długofalowym celem jest przezwyciężenie przyczyn uchodźstwa i stworzenie perspektyw życia ludziom w regionie. 
2016; Einzelplan 23, s. 48; Welthungerhilfe, 2016, s. 18). Pierwsza z nich zakłada doraźne wsparcie uchodźców i krajów przyjmujących, a także przeciwdziałanie takim zjawiskom jak ubóstwo, nierówność czy brak bezpieczeństwa żywnościowego. Niemieckie zaangażowanie rozwojowe ma służyć stworzeniu perspektyw samodzielnego życia dla uchodźców i zarazem wspierać społeczności przyjmujące poprzez budowę infrastruktury i zdolności. Celem drugiej inicjatywy jest pomoc w działaniach na rzecz pokoju, gospodarczej stabilizacji i promocji demokracji. Przykładem jest tworzenie miejsc pracy i możliwości kształcenia dla młodzieży w Egipcie i Tunezji. Ostatnia zmierza do wyeliminowania głodu i niedożywienia oraz stworzenia warunków pozwalających na wyżywienie rosnącej liczby ludności świata. W ramach inicjatywy wspierane są działania służące zatrudnieniu i wytwarzaniu dochodu na obszarach wiejskich, sprawiedliwemu dostępowi do ziemi i ochronie zasobów naturalnych.

W 2016 r. na przezwyciężanie przyczyn uchodźstwa - reintegrację uchodźców przewidziano $300 \mathrm{mln}$ euro (stabilizacja i rozwój w Afryce Pótnocnej i na Bliskim Wschodzie: $70 \mathrm{mln}$ euro, świat bez glodu: $220 \mathrm{mln}$ euro) (Bundeshaushaltsplan, 2016). Niemieckie zaangażowanie koncentruje się głównie na obszarach zapalnych w Syrii i państwach granicznych, a także w Iraku i Południowym Sudanie. Wspierano m.in. projekty mające na celu dostęp do wody pitnej dla syryjskich uchodźców w Jordanii i stabilizację relacji pomiędzy uchodźcami a społecznościami przyjmującymi. Według danych ONZ w 2015 r. Niemcy w ramach pomocy dla Syrii przekazały łącznie $524 \mathrm{mln}$ USD. Tym samym były czwartym największym dawcą po USA, Wielkiej Brytanii i Komisji Europejskiej (United Nations Office for the Cooperation of Humanitarian Affairs) (OCHA, 2015). W 2016 r. w planie pomocy humanitarnej ONZ dla Syrii Niemcy plasują się na pierwszym miejscu z $335 \mathrm{mln}$ USD, natomiast w ramach planu na rzecz uchodźców i budowania odporności w odpowiedzi na kryzys w Syrii na rok 2016 (the Syria Regional Refugee and Resilience Plan 3RP) wyasygnowały 576,6 mln USD (drugie miejsce po USA: 596,3 mln USD) (OCHA, 2016).

Przyjęty na rok 2017 budżet przewiduje wzrost środków BMZ do prawie 8 mld euro, w porównaniu z rokiem 2016 o $550 \mathrm{mln}$ euro (7\%). Od początku bieżącej kadencji budżet BMZ wzrósł o około 1,5 mld euro (23\%). Obok walki z kryzysem uchodźczym w centrum działań BMZ znajdują się walka z głodem, niedożywieniem, zmiany klimatu oraz tworzenie zrównoważonych łańcuchów dostaw. Ten wzrost w przekonaniu ministra Müllera odzwierciedla rosnące znaczenie polityki rozwojowej w rozwiązywaniu globalnych wyzwań. Jego zdaniem ,klucz do rozwiązania kryzysu uchodźczego leży w krajach pochodzenia. Polityka rozwojowa zapobiega przyczynom uchodźstwa i stwarza perspektywy mieszkańcom. Projekt budżetu na przyszły rok to uwzględnia. Rząd federalny stawia tym samym czoła rosnącym globalnym wyzwaniom. Umożli-

${ }^{4}$ W następstwie konferencji w sprawie Syrii 18 grudnia 2014 r. w Berlinie przedstawione zostały programy pomocowe ONZ dla Syrii i państw sąsiadujących: Syria Response Plan - SRP (obecnie Humanitarian Response Plan - HRP) i Syria Regional Refugee and Resilience Plan 2015-2016 (3RP). Plany przewidywały zapotrzebowanie na rok 2016 w kwocie 7,8 mld USD. Obejmuja one zarówno środki wsparcia syryjskich uchodźców, jak również gmin przyjmujących w krajach sąsiadujących, jak Turcja, Jordania, Liban, Irak i Egipt. Celem 3RP jest powiązanie/zintegrowanie ochrony uchodźców i pomocy humanitarnej z działaniami rozwojowymi, pozwalającymi na wzmocnienie odporności jednostek, gmin i instytucji w obliczu kryzysów. 
wia to kontynuację i wzmocnienie ważnych projektów BMZ w zakresie kryzysu syryjskiego i irackiego, w Afryce, ale także w regionach kryzysowych jak na Ukrainie" (BMZ, 2016).

Część finansowanych przez BMZ projektów dotyczących uchodźców przebiega w ramach trzeciej wspomnianej inicjatywy Stabilizacja i rozwój Afryki Pótnocnej $i$ Bliskiego Wschodu. Z tych środków pokrywane są m.in. doraźne potrzeby uchodźców w Libanie, wsparcie zatrudnienia młodzieży, zrównoważony rozwój gospodarczy, transparencja, praworządność i wolność słowa. W 2014 r. beneficjentami obok Libanu i Jordanii były Maroko, Egipt, Tunezja, Jemen, Obszary Palestyńskie i Mauretania.

Zdecydowaną przewage w niemieckiej współpracy rozwojowej mają działania realizowane bilateralnie: w 2014 r. było to 74,3\% łącznej ODA, natomiast $25,7 \%$ stanowiły wkłady do budżetów organizacji multilateralnych. Ponadto $6,2 \%$ bilateralnej ODA przeznaczono na projekty realizowane przez organizacje wielostronne (środki powiązane celowo) (OECD, 2016b, s. 199) $)^{5}$. Na wsparcie krajów niestabilnych przeznaczono 3,8 mld USD (26,8\% bilateralnej ODA) (OECD, 2016b, s. 200). Programy niemieckiej współpracy rozwojowej wypracowywane są w ramach bilateralnych negocjacji z rządami krajów partnerskich. Omówione wyżej trzy inicjatywy nie są przypisane do konkretnego kanału alokacji środków w ramach niemieckiego systemu współpracy rozwojowej. Jest to zasadnicza zmiana w sposobie pracy BMZ, która stwarza ministerstwu możliwość wyboru odpowiedniego instrumentarium i partnerów (OECD, 2016b, s. 19).

Niemieckie wsparcie rozwojowe na Ukrainie sięga 20-letniej tradycji i koncentruje się przede wszystkim na zrównoważonym rozwoju gospodarczym, sektorze energetycznym i przeciwdziałaniu HIV/AIDS. W reakcji na kryzys ukraiński Niemcy potroiły dotychczasowe regularne wsparcie do $70 \mathrm{mln}$ euro. W $2014 \mathrm{r}$. Ukraina otrzymała 45,5 mln euro w ramach niemieckiej pomocy rozwojowej, m.in. BMZ przekazało kontenery mieszkalne dla 4 tys. wewnętrznych uchodźców (BMZ, 2014b). W listopadzie 2015 r. na mocy porozumienia międzyrządowego Niemcy zobowiązały się do przekazania łącznie $177 \mathrm{mln}$ euro pomocy rozwojowej. Na lata 2015-2018 przewidziano cztery inicjatywy, służące wsparciu ukraińskich władz w odbudowie i opiece nad wewnętrznymi uchodźcami: 1) wzmocnienie ukraińskiej prewencji w zakresie

${ }^{5}$ Mimo że udział multilateralnej ODA w ostatnich pięciu latach sukcesywnie się zmniejszał, Niemcy priorytetowo traktują podstawowe finansowanie multilateralnych organizacji. M.in. w 2013 r. Niemcy podwoiły swój wkład do programów ONZ mających na celu pomoc humanitarną dla Syrii. BMZ wspiera pracę organizacji pomocowych w obszarze kształcenia, ochrony dzieci, dostępu do wody i kanalizacji. Za pośrednictwem UNICEF Niemcy przekazały 99 mln euro na libański program Reaching all Children with Education (RACE), który jest częścią międzynarodowej inicjatywy No lost Generation. Innym przykładem jest budowa systemu kanalizacyjnego w obozie dla uchodźców w Za'atari w Jordanii (UNICEF 15 mln euro). Ze specjalnych środków BMZ dla Światowego Programu Żywnościowego (WFP) uchodźcy w Libanie i Iraku otrzymują bony na zakupy w prywatnych sklepach. Wzmacnia to lokalną gospodarkę, stwarza miejsca pracy w handlu detalicznym i zapobiega konfliktom między uchodźcami i gminami przyjmującymi. Na konferencji w Londynie 4 lutego 2016 r. rząd federalny zainicjował inicjatywę na rzecz zatrudnienia na Bliskim Wschodzie. Program Cash-for-Work stwarza możliwości zatrudnienia dla uchodźców i lokalnych mieszkańców i jednocześnie wspiera budowę szkół, szpitali i centrów gminnych. Służy on m.in. niwelowaniu napięć pomiędzy uchodźcami a miejscowymi. Do początku 2017 r. planuje się stworzenie 50 tys. miejsc pracy (www.bmz.de). 
zapobiegania katastrofom przez kształcenie i doradztwo współpracowników, dostarczanie wyposażenia oraz artykułów użytku osobistego i domowego dla uchodźców; 2) wzmocnienie społeczności przyjmujących: działania w zakresie kształcenia zawodowego, możliwości spędzania wolnego czasu dla młodzieży, wzmocnienie zdolności leczenia traumy i radzenia sobie z sytuacjami kryzysowymi, jak i wsparcie społeczności przyjmujących w oferowanej infrastrukturze społecznej; 3) polepszenie sytuacji mieszkalnej uchodźców w utrzymaniu i doradztwie np. przy planowaniu budżetu; 4) odbudowa zniszczonych ulic, mostów i instytucji publicznych, jak szpitale i szkoły. Ponadto rząd federalny udzielił gwarancji pożyczek w wysokości do $500 \mathrm{mln}$ euro, zaciąganych za pośrednictwem KfW Entwicklungsbank. Służą one modernizacji infrastruktury i odbudowie mieszkań.

Organizacje pozarządowe terre des hommes i die Welthungerhilfe w corocznym raporcie oceniającym niemiecką politykę rozwojową w 2015 r. wezwały rząd do konsekwentnego urzeczywistniania Celów Zrównoważonego Rozwoju (SDG) i tym samym wyraźnego wkładu w zwalczanie źródeł uchodźstwa. Postulowały zainicjowanie nowej niemieckiej i europejskiej polityki migracyjnej, która powinna oprzeć się na czterech punktach: 1) przezwyciężeniu czynników wywołujących zjawisko uchodźstwa, a nie tylko jego symptomów np. silniejsze zaangażowanie w prewencję kryzysowa, 2) większym finansowym wsparciu dla krajów pochodzenia i ich sąsiadów, 3) wypracowaniu trwałej koncepcji migracyjnej i ułatwieniu integracji, np. stwarzając lepszy dostęp migrantów do edukacji, 4) zapobieganiu katastrofom humanitarnym, stwarzaniu legalnych możliwości migracji, np. dzięki udostępnianiu wiz humanitarnych czy ułatwienia w sprowadzaniu rodzin. Ponadto należy wyjść poza inicjatywę przezwyciężanie przyczyn uchodźstwa - reintegrację uchodźców (obecnie funkcjonująca jako zespół roboczy Uchodźstwo i Migracja), wzbogacając migracyjną ofertę programową współpracy na rzecz rozwoju. Co więcej, Niemcy „potrzebują nowej polityki integracyjnej, wdrażanej już w momencie przyjęcia uchodźców", ponieważ wielu z nich zostanie imigrantami, którym „,[...] zależy na społecznym zaangażowaniu i w dłuższej perspektywie mogą tu wnieść spory wkład" (Welthungerhilfe, 2016, s. 28-29).

W 2016 r. BMZ rozpoczęło prace nad rządowym sprawozdaniem w sprawie przyszłości polityki rozwojowej, które ma zostać opublikowane wiosną 2017 r. (Bericht der Bundesregierung zur Zukunft der Entwicklungspolitik, Weißbuch 2017). Merytorycznie ma się on koncentrować na realizacji Agendy 2030 dla zrównoważonego rozwoju oraz uwzględniać zewnętrzne impulsy od społeczeństwa obywatelskiego, świata gospodarki, nauki i polityki. Na zorganizowanej przez BMZ konferencji zatytułowanej Rozwój, bezpieczeństwo i pokój w czerwcu 2016 r. przedstawione zostały główne założenia przygotowywanego dokumentu. W dyskusji uczestniczyli minister współpracy rozwojowej Gerd Müller, minister obrony Ursula von der Leyen oraz 150 przedstawicieli: Bundestagu, pozostałych resortów, niemieckich i międzynarodowych organizacji rozwojowych i działających na rzecz pokoju. W swojej wypowiedzi minister Müller potwierdził rosnace znaczenie polityki rozwojowej dla prewencji kryzysowej. Wezwał do zmiany paradygmatu w kierunku ,powiązanego rozwoju”, współdziałania polityki zagranicznej, rozwojowej, bezpieczeństwa, klimatycznej, ochrony środowiska i europejskiej. Agenda 2030 wyznacza ramy tych działań. Polityka rozwojowa jest w jego przekonaniu najlepszą polityką na rzecz pokoju. Pierwszeństwo mają instrumenty cy- 
wilne, interwencja nie może być ultima ratio. Z kolei „tam gdzie walczy się o pokój, należy zatroszczyć się o rozwój”. Mandat Bundeswehry również powinien charakteryzować się ,zintegrowanym podejściem”. To kompleksowe podejście jest niezbędne w obliczu kryzysu uchodźczego, bowiem w przekonaniu Müllera „uchodźcy, którzy trafiają do Europy są wyraźnym znakiem na to, co się stanie jeśli nic się nie stanie! Same tylko klasyczne środki polityki bezpieczeństwa nam nie wystarczą. Nie rozwiążą problemów". W odniesieniu do Afryki ważna w przekonaniu ministra jest pomoc partnerom, jak Unia Afrykańska w budowaniu samodzielnej zdolności rozwiązywania kryzysów. Z kolei niezbędnym elementem szybkiej reakcji na sytuację kryzysową jest zapewnienie środków finansowych. Müller powtórzył swój postulat zgłoszony na Światowym Szczycie Humanitarnym (WHS) w Istambule w maju 2016 r. utworzenia funduszu pomocowego ONZ, który składałby się z obowiązkowych wkładów państw członkowskich ONZ. Zapewnienie rozwoju dla pokoju wymaga inwestycji. Minister Müller wezwał do inwestycji ,w całkiem nowe płaszczyzny rozwoju” dla wszystkich. Globalna oficjalna pomoc rozwojowa (ODA) musi zostać podwojona i pozostać „W nowej równowadze” w stosunku do wydatków zbrojeniowych, które obecnie przewyższają ODA ponad dziesięciokrotnie. Podkreślił dobrą współpracę międzyresortową przy wypracowaniu Białej Księgi w sprawie polityki bezpieczeństwa i przyszłości Bundeswehry z 2016 r. Zapowiedział kontynuację ponadresortowej współpracy przy opracowaniu Sprawozdania rzadu w sprawie przyszłości polityki rozwojowej, który ma być opublikowany wiosną 2017 r. (Müller, 2016). Również minister von der Leyen zapewniła, że „myślimy sieciowo i całościowo”. Z „niezwykle ścisłej i pragmatycznej współpracy pomiędzy BMZ i GIZ ${ }^{6}$ z jednej strony i BMVg7 oraz Bundeswehry z drugiej strony" oba ministerstwa mogą się od siebie uczyć (FriEnt, 2016).

Na zakończenie swojego wystapienia Müller stwierdził, że ,,nie osiągniemy większego rozwoju na rzecz pokoju za darmo. Ale jeśli ktoś sądzi, że musimy budować ogrodzenia, by bronić naszego dobrobytu, zapłaci wysoką cenę. Niemcy stanowią zaledwie 1,2\% światowej populacji, Europa 7\%. Jesteśmy częścią globalnej wioski: jeden świat - nasza odpowiedzialność. Angażujemy się bardziej w regionach kryzysowych. Bo jeśli nie będziemy się tam mocniej prewencyjnie angażować, problemy przyjdą do nas" (Müller, 2016).

\section{Uwagi końcowe}

Od samych początków polityka rozwojowa RFN była nieodłączną częścią ewoluującej na przestrzeni lat niemieckiej polityki zagranicznej i handlowej. Świadomość „,nowych zagrożeń”, jak rosnąca presja migracyjna czy ruchy fundamentalistyczne, wpłynęła na przypisanie jej nowej - obok humanitarnej - funkcji ,,prewencyjnej polityki bezpieczeństwa" w ramach koncepcji ,,powiązanego bezpieczeństwa”. Niemiecka polityka rozwojowa charakteryzuje się wysokim stopniem ciagłości i ponadpartyjnego konsensusu, kolejni ministrowie z różnym efektem dążą do nadania jej „,nowych akcentów”. Minister Gerd Müller, podobnie do swojej socjaldemokratycznej poprzed-

${ }^{6}$ Deutsche Gesellschaft für Internationale Zusammenarbeit.

${ }^{7}$ Das Bundesministerium der Verteidigung, Federalne Ministerstwo Obrony. 
niczki Heidemarie Wieczorek-Zeul, buduje niemiecką współpracę rozwojową przez pryzmat inwestycji we własne bezpieczeństwo i poczucie współodpowiedzialności. Kompleksowa odpowiedź na masowy napływ uchodźców powinna przyczyniać się zarówno do zapobiegania przyczynom tego zjawiska, jak i minimalizowania jego konsekwencji, którego źródła tkwią w dysfunkcyjności i niestabilności krajów rozwijających się. To podejście można odnaleźć w przedstawionej 13 lipca 2016 r. przez rząd federalny Białej Księdze o polityce bezpieczeństwa RFN i przyszłości Bundeswehry. Przeciwdziałanie źródłom uchodźstwa i nielegalnej migracji wymaga „wspólnych wysiłków społeczności międzynarodowej oraz krajów pochodzenia i tranzytu. Szczególne znaczenie przypisuje się wsparciu osób wewnętrznie przesiedlonych i uchodźców w państwach przyjmujących, bezpośredniego sąsiedztwa" (Bundesregierung, 2016, s. 42). Zatem polityka rozwojowa ma być prewencyjną polityką na rzecz pokoju. Co prawda niemieckiej polityce rozwojowej nie brakuje dobrych pomysłów i intencji, jednakże, jak podkreśla Franz Nuscheler „była i jest zakleszczona pomiędzy kalkulacją bezpieczeństwa, interesami politycznymi i gospodarczymi a moralnością" (Nuscheler, 2012, s. 319). Jednym z obszarów działań, który wskazuje Karta przyszłości z 2014 r. jest „kształtowanie pokoju i wzmocnienie bezpieczeństwa”. Kłóci się on zatem z istotną pozycja, jaką Niemcy odgrywaja jako światowy eksporter uzbrojenia - w latach 2011-2015 znajdowały się w pierwszej piątce za USA, Rosją, Chinami i Francją (SIPRI, 2016). Rok 2015 miał być pod tym względem „rekordowy”, już w pierwszej połowie zatwierdzona wielkość uzbrojenia przeznaczonego na eksport osiagnęła prawie wartość z roku 2014 (Elmer, 2015). W okresie rządów kanclerz Angeli Merkel udział niemieckiego eksportu uzbrojenia poza kraje UE i NATO średnio stanowił 47\%, przy czym od 2012 r. było to ponad 50\%, a w 2015 r. 59\%. W 2015 r. eksport do krajów Bliskiego Wschodu i Afryki Północnej wzrósł aż o 144\% (Schmidt, 2016, s. 271). Wśród 10 najważniejszych odbiorców znajdują się Arabia Saudyjska, Izrael i Kuwejt. Reasumując powyższe rozważania, nasuwa się kontrowersyjna konstatacja, że w dużej mierze "ten kto dostarcza broń, pobudza do wojen i zmusza ludzi do ucieczki” (Schmidt, 2016), a zatem polityka rozwojowa jest w tym przypadku również wyrazem „współodpowiedzialności”.

\section{Bibliografia}

Bauer S., Schraven B. (2014), Konflikte, Krisen, Klimawandel. Deutschlands globale Verantwortung fur eine zukunftsfahige Migrationspolitik, www.diplomatisches-magazin.de, 10.07.2016.

Bilzen van G. (2015), The development of Aid, Cambridge Scholars Publishing.

BMZ (1995), Zehnter Bericht zur Entwicklungspolitik der Bundesregierung, http://dip21.bundestag. de/dip21/btd/13/033/1303342.pdf, 12.07.2016.

BMZ (2001), Elfter Bericht zur Entwicklungspolitik der Bundesregierung, http://fa1.spd-berlin.de/ Dokumente/bregez11.pdf, 12.07.2016.

BMZ (2014), Die Zukunftscharta „EINEWELT - Unsere Verantwortung 2014, https://www.zukunftscharta.de/das-dokument.html, 12.07.2016.

BMZ (2014a), Die neue Politik des BMZ100-Tage-Bilanz von Bundesentwicklungsminister Dr. Gerd Müller, www.pressebox.de/.../28+Anl+100+Tage+Bilanz.pdf, 12.07.2016. 
BMZ (2014b), http://www.bmz.de/de/presse/aktuelleMeldungen/2014/oktober/141014_pm_099 Bundesminister-Mueller-in-der-Ostukraine-Jahrzehntelange-Freundschaft-bewaehrt-sichjetzt-in-der-Krise1/index.html, 12.07.2016.

BMZ (2016), Bundesregierung stärkt Entwicklungspolitik, http://www.bmz.de/de/presse/aktuelleMeldungen/2016/maerz/160323_pm_025_Bundesregierung-staerkt-Entwicklungspolitik/ index.html, 12.07.2016.

BMZ (2016a), http://www.bmz.de/de/themen/Sonderinitiative-Fluchtursachen-bekaempfen-Fluechtlinge-reintegrieren/deutsche_politik/index.jsp, 12.07.2016.

BMZ Syrien (2016), http://www.bmz.de/de/laender_regionen/naher_osten_nordafrika/syrien/index. html, 12.07.2016.

bpb (2016), https:/www.bpb.de/politik/innenpolitik/flucht/218788/zahlen-zu-asyl-in-deutschland\#Antraege, 12.07.2016.

Brown S., Grävingholt J. (red.) (2016), The Securitization of Foreign Aid, Palgrave Macmillan, Hampshire.

Bundeshaushaltsplan (2015), Einzelplan 23, https://www.bundeshaushalt-info.de/fileadmin/de.bundeshaushalt/content_de/dokumente/2015/soll/ep123.pdf\#page=11, 12.07.2016.

Bundeshaushaltsplan (2016), Einzelplan 23, https://www.bundeshaushalt-info.de/\#/2016/soll/ausgaben/einzelplan/2310.html, 12.07.2016.

Bundesregierung (2013), Deutschlands Zukunft gestalten Koalitionsvertrag zwischen CDU, CSU und SPD, 18.Legislaturperiode, s. 180, https://www.bundesregierung.de/Content/DE/_Anlagen/2013/2013-12-17-koalitionsvertrag.pdf?_blob=publicationFile\&v=2, 10.07.2016.

Bundesregierung (2016), Weißbuch 2016 - zur deutschen Sicherheitspolitik und zur Zukunft der Bundeswehr.

Duffield M. (2007), Development, Security and Unending War: Governing the World of Peoples, Polity Press, Cambridge.

Elmer Ch. (2015), Genehmigungen gestiegen: In diesen Ländern landen deutsche Rüstungsgüter, „Spiegel Online”, 9.08.2015, http://www.spiegel.de/politik/deutschland/ruestungsexportean-diese-laender-liefert-deutschland-a-1047395.html, 12.07.2016.

Fijałkowski Ł. (2012), Teoria sekurytyzacji i konstruowanie bezpieczeństwa, „Przegląd Strategiczny", nr 1, http://studiastrategiczne.amu.edu.pl/?p=895, 12.07.2016.

FriEnt (2016), https://www.frient.de/en/news/details/news/bmz_konferenz_entwicklung_sicherheit_und_frieden_wie_kann_gemeinsame_krisen_und_konfliktbewaeltigung_verbessert_werden/, 12.07 .2016 .

Grävingholt J., Schraven B. (2016), Kriege, Flüchtlinge und eine ,Systemkrise”: die internationale Nothilfe muss reformiert werden, „Die aktuelle Kolumne”, 23.05.2016, Deutsches Institut für Entwicklungspolitik.

Hacke Ch. (2003), Die Außenpolitik der Bundesrepublik Deutschland. Von Konrad Adenauer bis Gerhard Schröder, Frankfurt/M-Berlin.

Hackenesch Ch., Leininger J. (2015), Entwicklungspolitische Beiträge zu einer europäischen Flüchtlingspolitik, „Die aktuelle Kolumne”, 5.05.2015, Deutsches Institut für Entwicklungspolitik.

Harmer A., Macrea J. (red.) (2004), Beyond the continuum. The changing role of aid policy in protracted crises, Humanitarian Policy Group Research Report 18, https://www.odi.org/sites/ odi.org.uk/files/odi-assets/publications-opinion-files/279.pdf, 12.07.2016.

Koalitionsausschuss am 6.09.2015 (2015), http://www.cdu.de/system/tdf/media/dokumente/150906ergebnis-koalitionsausschuss.pdf?file=1\&type=fieldcollectionitem\&id=2360, 12.07.2016.

Krause U. (2013), Linking Refugee Protection with Development Assistance, Nomos Verlagsgesellschaft, Baden-Baden. 
Messner D. (2015), Große Ideen für große Probleme gesucht, „Zeit Online”, 10.09.2015, http://www. zeit.de/politik/2015-09/fluechtlingskrise-fuenf-punkte-plan, 12.07.2016.

Messner D. (2015a), Deutschland als Gestaltungsmacht in der globalen Nachhaltigkeitspolitik - Chancen und Herausforderungen unter den Bedingungen , umfassender Globalisierung”, w: ,Früher, entschiedener und substantieller”? Die neue Debatte über Deutschlands Außenpolitik, „ZFAS Sonderheft”, nr 6, s. 379-394.

Messner D. (2016), Weltkrisen, Weltschichten, Wegscheiden, „Die aktuelle Kolumne”, 11.01.2016, Deutsches Institut für Entwicklungspolitik.

Messner D., Weinlich S. (red.) (2016), Global Cooperation and the Human Factor in International Relations, Routledge-London-New York.

Müller G. (2014), Die Lage der syrischen Flüchtlinge - Stabilität in der Region unterstützen Rede von Bundesentwicklungsminister Dr. Gerd Müller bei der Syrien-Konferenz am 28. Oktober 2014 in Berlin, http://www.bmz.de/de/presse/reden/minister_mueller/2014/Oktober/20141028_ syrien-konferenz.html, 12.07.2016.

Müller G. (2016), Entwicklung, Sicherheit, Frieden, Rede von Minister Müller bei einer Konferenz im Rahmen der Erstellung des Berichts der Bundesregierung zur Zukunft der Entwicklungspolitik 2017 in Berlin, http://www.bmz.de/de/presse/reden/minister_mueller/2016/juni/160606_ Rede-Minister-Mueller-bei-Konferenz-im-Rahmen-der-Erstellung-des-Berichts-der-Bundesregierung-zur-Zukunft-der-Entwicklungspolitik-2017.html, 12.07.2016.

Nuscheler F. (2012), Entwicklungspolitik, Dietz, Bonn.

OCHA (2015), https://fts.unocha.org/pageloader.aspx?page=search-reporting_display\&CQ= cq020315114425TxF7oSVtRX, 12.07.2016.

OCHA (2016), https://fts.unocha.org/reports/daily/ocha_R5_A1133__1608220231.pdf, 12.07.2016.

OECD (2012), ODA reporting of in-donor country refugee costs. Members 'methodology for calculating costs. Paris, www.oecd.org/dac/stats/RefugeeCostsMethodological-Note.pdf.

OECD (2015), DAC-Prüfbericht über die Entwicklungszusammenarbeit: Deutschland 2015, http:// www.keepeek.com/Digital-Asset-Management/oecd/development/dac-prufbericht-uber-dieentwicklungszusammenarbeit-deutschland-2015_9789264246157-de\#page1.

OECD (2016a), Development aid in 2015 continues to grow despite costs for in-donor refugees, 2015 Preliminary ODA Figures, http://www.oecd.org/dac/stats/ODA-2015-detailed-summary.pdf, 12.07.2016.

OECD (2016b), Development Co-operation Report 2016, http://www.oecd.org/dac/development-cooperation-report-20747721.htm, 12.07.2016.

Paterek A. (2015), Polityka rozwojowa Niemiec jako czynnik stabilizacji i bezpieczeństwa państw upadtych na przykładzie Afganistanu i państw Afryki Subsaharyjskiej, „Krakowskie Studia Międzynarodowe", nr 1, s. 171-188.

Schmidt D. (2016), Die deutsche Rüstungspolitik. Wer Waffen liefert, heizt Kriege an und treibt Menschen in die Flucht, „Prokla Heft 183”, nr 2, s. 267-288.

Schraven B., Keijzer N. (2014), Die globale Flüchtlingskrise erfordert mehr als nur humanitare Hil$f e$, „Die aktuelle Kolumne”, 23.06.2014, Deutsches Institut für Entwicklungspolitik.

Schraven B., Keijzer N., Knoll A. (2014), Post 2015: Migration im Sinne einer nachhaltigen Entwicklung gestalten, „Analysen und Stellungnahmen”, nr 1, Deutsches Institut für Entwicklungspolitik.

Schraven B., Trautner B., Leininger J., Loewe M., Grävingholt J. (2015), Was kann Entwicklungspolitik zur Bekämpfung von Fluchtursachen beitragen?, „Analysen und Stellungnahmen”, nr 14, Bonn, German Development Institute/Deutsches Institut für Entwicklungspolitik (DIE).

SIPRI (2016), Trends in international arms transfers, 2015, SIPRI Fact Sheet Februar 2016, http:// books.sipri.org/files/FS/SIPRIFS1602.pdf, 12.07.2016. 
Sommer T. (2015), Kein Hilfsgeld für korrupte Kleptokraten, „Zeit Online”, 28.04.2015, http:// www.zeit.de/politik/ausland/2015-04/fluechtlinge-mittelmeer-ursachen-entwicklungshilfe, 12.07.2016.

Stockmann R., Menzel U., Nuscheler F. (2016), Entwicklungspolitik. Theorien-Probleme - Strategien, 2.Auflage, Berlin/Boston.

Trautner B. (2015), Zur Bekämpfung der tatsächlichen Fluchtursachen in Syrien, „Die aktuelle Kolumne", 8.10.2015, Bonn, German Development Institute/Deutsches Institut für Entwicklungspolitik (DIE).

UNHCR (2016), Global Trends Forced displacement 2015, http://www.unhcr.org/statistics/unhcrstats/576408cd7/unhcr-global-trends-2015.html, 12.07.2016.

Welthungerhilfe (2016), Die Wirklichkeit der. Entwicklungspolitik 2015, http://www.welthungerhilfe.de/bericht-wirklichkeit-entwicklungspolitik.html, 12.07.2016.

\section{Streszczenie}

Kryzys migracyjny jest niewątpliwie jednym z najważniejszych tematów wyznaczających obecnie niemiecką i europejską debatę publiczną. Artykuł analizuje wkład niemieckiej współpracy rozwojowej w przezwyciężanie sytuacji patowej spowodowanej masowym napływem imigrantów do Europy. Niemieckie zaangażowanie koncentruje się przede wszystkim na zwalczaniu strukturalnych przyczyn uchodźctwa, wsparciu uchodźców i stabilizacji regionów przyjmujących. Ukazane zostały m.in. założenia inicjatywy Federalnego Ministerstwa Współpracy Gospodarczej i Rozwoju (BMZ) Zwalczanie przyczyn uchodźctwa - reintegracja uchodźców oraz jej realizacja.

Słowa kluczowe: współpraca rozwojowa, kryzys uchodźczy, ODA, Niemcy

\section{Overcoming the refugee crisis in the $\mathrm{EU}$ from the point of view of German development policy}

\section{Summary}

The refugee crisis has become one of the most important topics on the EU's and also Germany's domestic political agenda. This paper analyses the contribution of the German development policy to deal with the growing influx of refugees from war zones and crisis areas into Europe. It deals with the question of the role of the development policy to forestall displacement. The German activities address three areas of intervention: tackling the root causes of displacement, supporting of refugees and stabilising host regions. The analysis take look at - among others - an initiative launched by the Federal Ministry for Economic Cooperation and Development (BMZ) to Tackling the root causes of displacement, reintegrating refugees.

Key words: development policy, refugee crisis, ODA, Germany 
